\title{
TAHAP KEMAHIRAN DAN KECENDERUNGAN PEMIKIRAN KRITIS MURID TINGKATAN DUA DALAM MATA PELAJARAN KEMAHIRAN HIDUP BERSEPADU (KHB) DI NEGERI KEDAH DAN HUBUNGANNYA
}

\section{(THE LEVEL OF CRITICAL THINKING SKILL AND DISPOSITION OF FORM TWO STUDENTS IN INTERGRATED LIVING SKILL SUBJECT IN KEDAH AND ITS RELATIONSHIP)}

\author{
Mohd Fadzil Mohd Rosdi*, Suhaida Abdul Kadir and Mohd Ibrahim Nazri \\ Faculty of Educational Studies, Universiti Putra Malaysia, 43400 Serdang, \\ Selangor, Malaysia \\ *Corresponding author: padilmfmr@gmail.com
}

Published date: 10 August 2018

To cite this article: Mohd Fadzil Mohd Rosdi, Suhaida Abdul Kadir, \& Mohd Ibrahim Nazri. (2017). Tahap kemahiran dan kecenderungan pemikiran kritis murid tingkatan dua dalam mata pelajaran Kemahiran Hidup Bersepadu (KHB) di negeri Kedah dan hubungannya. Asia Pacific Journal of Educators and Education, 32, 45-60. https://doi.org/10.21315/apjee2017.32.4

To link to this article: https://doi.org/10.21315/apjee2017.32.4

\begin{abstract}
Abstrak: Penyelidikan ini menilai tahap kemahiran pemikiran kritis dan tahap kecenderungan pemikiran kritis dalam kalangan murid tingkatan dua di Sekolah Menengah Kebangsaan di Daerah Kuala Muda dan Yan, Kedah dan melihat hubungan antara kedua-dua pemboleh ubah. Dimensi-dimensi kemahiran pemikiran kritis yang dianalisis dalam kajian ini ialah 1) Induksi; 2) Deduksi; 3) Kredibiliti Peryataan; dan 4) Mengenal Pasti Andaian manakala bagi tahap kecenderungan pemikiran kritis murid pula meliputi aspek inoviasi, kematangan kognitif dan juga penglibatan. Instrumen yang digunakan dalam kajian ini ialah ujian pemikiran kritis Cornell (Cornell Critical Thinking Test) bagi menilai tahap pemikiran kritis dan bagi mengukur tahap kecenderungan pemikiran kritis menggunakan instrumen University of Florida - Engagement, Maturity and Innovativeness (UF/EMI). Kedua-dua instrument ini diadaptasikan ke dalam bahasa Melayu dan diberi pengujian secara rawak kepada 370 orang murid. Analisis data menggunakan statistik deskriptif seperti min, sisihan piawai dan peratusan. Manakala statistik inferensi juga digunakan untuk menganalisis data iaitu Korelasi Pearson bagi melihat hubungan antara kedua-dua pemboleh ubah. Dapatan kajian menunjukkan bahawa tahap kemahiran pemikiran kritis
\end{abstract}


murid tingkatan dua dalam mata pelajaran Kemahiran Hidup Bersepadu (KHB) di negeri Kedah berada pada tahap lemah. Manakala tahap kecenderungan pemikiran kritis berada pada tahap kuat dan hubungan antara kemahiran pemikiran kritis dengan kecenderungan pemikiran kritis pula menunjukkan wujudnya hubungan yang positif antara kedua-dua pembolehubah.

Kata kunci: kemahiran pemikiran kritis, kecenderungan pemikiran kritis, Kemahiran Hidup Bersepadu (KHB), tingkatan dua, CCTT-X, hubungan

\begin{abstract}
This research evaluates the level of critical thinking skills and the disposition of critical thinking among the form students from two secondary schools in Kuala Muda and Yan, Kedah and the relationship between the two variables. The dimensions of critical thinking skills that are analysed in this study were 1) Induction; 2) Deduction; 3) The credibility of the statement; and 4) Identifying Assumptions and for the level of critical thinking disposition students were inovation aspect, and also the involvement aspect and cognitive maturity aspect. The instrument used in this study are Cornell Critical Thinking Test to evaluate the level of critical thinking and to assess the level of critical thinking disposition to use instruments of University of Florida - Engagement, Maturity and Innovativeness (UF/EMI). Both the instrument is adapted to the Malay and testing randomly assigned to 370 students. Data were analysed using descriptive statistics such as mean, standard deviation and percentage. While statistical inference is also used to analyse the data for the Pearson correlation between the two variables. The findings showed that the level of critical thinking skills of students in form two in intergrated living skills subjects at Kedah are on the lower level. While the tendency is on critical thinking disposition were strong relationship between the level of critical thinking skills and critical thinking disposition showed a positive relationship between the two variables.
\end{abstract}

Keywords: critical thinking skills, critical thinking disposition, integrated living skills subject, CCTT-X, relationship

\title{
PENGENALAN
}

Pembangunan masyarakat yang memiliki kemahiran berfikir yang tinggi (Aras Tinggi) merupakan satu agenda penting dalam pembangunan bangsa dan pembinaan negara. Pendidikan yang berkualiti dapat melahirkan masyarakat yang memiliki kemahiran berfikir bagi menghadapi kemajuan dan cabaran serta gelombang perubahan global pada abad ke-21. Pendidikan negara merupakan satu reformasi terpenting dalam pembentukan masyarakat dan juga dapat membentuk satu negara yang maju dalam pelbagai bidang seperti kebudayaan, sains dan teknologi, informasi maklumat, kemahiran berfikir dan budaya ilmu. Dengan ini, ia bertepatan dengan matlamat yang diperhalusi dalam Falsafah Pendidikan Negara (FPN), iaitu perkembangan daya intelek telah diberi penekanan utama bersama- 
sama dengan perkembangan rohani, emosi dan jasmani. Oleh itu, kemahiran berfikir telah dijadikan satu daripada elemen utama dan penting dalam sistem pendidikan negara.

Sistem pendidikan kita merupakan tulang belakang pembangunan negara, dimana ianya akan melahirkan generasi yang akan datang yang merupakan pemimpin pada masa hadapan. Sistem pendidikan ini dapat menyediakan ilmu pengetahuan dan kemahiran kepada generasi kini dan generasi sebelumnya bagi memacu pertumbuhan ekonomi dan memakmurkan negara. Jesteru itu, Kementerian Pendidikan Malaysia telah melancarkan transformasi pendidikan dalam sistem pendidikan Negara pada tahun 2013 melalui Pelan Pembangunan Pendidikan Malaysia 2013-2025 (PPPM) (Kementerian Pendidikan Malaysia, 2013). Pelan Pembangunan Pendidikan Malaysia (PPM) bukan sekadar hanya menambah bilangan kakitangan dan kemudahan atau fasiliti, malah kepada usaha untuk memahami dan menambah baik dinamik proses pengajaran dan pembelajaran serta keberhasilan dan kemenjadian murid. Transformasi ini diharapkan dapat melahirkan satu generasi yang berpengetahuan, mampu berfikir secara kritis dan kreatif, mempunyai kemahiran kepimpinan yang mantap dan berupaya berkomunikasi dengan berkesan pada peringkat global.

Kemahiran berfikir secara kritis merupakan satu kemahiran yang penting dan perlu diterapkan ke dalam pemikiran pelajar. Di dalam sistem pendidikan di Malaysia, elemen kemahiran berfikir pelajar mula diberi perhatian dan dianggap penting kerana ianya merupakan satu elemen tambah nilai kepada pelajar bagi menghadapi masa hadapan yang lebih mencabar. Kemahiran ini amat penting bagi mencapai hasrat negara untuk melahirkan satu generasi pewaris yang berupaya untuk berfikir aras tinggi seterusnya dapat menjadi generasi yang berdaya saing sehingga ke peringkat global. Ini ditegaskan oleh Perdana Menteri Malaysia dalam ucapannya bertajuk, Education Transformation to Create Thinking Generation, iaitu "The world has changed. We need to prepare the present generation to face the world of the future which will surely be much different from that of today" (Mohd. Najib Razak, 2012).

Selaras dengan itu, kementerian juga menyemak semula kurikulum pendidikan untuk menerap dan membangunkan kemahiran abad ke-21 yang menekankan elemen berfikiran kritis dan kreatif, serta menggalakkan perkembangan sahsiah murid yang holistik dan seimbang (Muhyidin Mohd Yassin, dalam Pelan Pembangunan Pendidikan 2013-2025 [Kementerian Pelajaran Malaysia, 2013]). Bagi bersaing dengan negara maju adalah penting untuk Malaysia menyediakan pendidikan berkualiti yang mampu menghasilkan murid bertaraf dunia dan mempunyai kemahiran-kemahiran kritikal abad ke-21. 
Kemahiran Hidup Bersepadu (KHB) mula diperkenalkan sebagai satu mata pelajaran amali yang berteraskan kepada teknologi. Mata pelajaran Kemahiran Hidup Bersepadu ditawarkan kepada semua murid di Tingkatan satu hingga Tingkatan tiga di peringkat menengah rendah. Objektif utama mata pelajaran ini diperkenalkan adalah untuk mempertingkatkan produktiviti negara melalui penglibatan masyarakat secara kreatif, inovatif dan produktif. Selain daripada itu, mata pelajaran Kemahiran Hidup Bersepadu juga menekankan kemahiran berfikir secara kritis dan kreatif dalam pengajaran dan pembelajaran yang mana daya imaginasi dan kreativiti murid perlu dijanakan dan diperkembangkan (Kementerian Pendidikan Malaysia, 2002).

Banyak penyelidikan telah dijalankan untuk mengkaji kemahiran berfikir secara kritis dan kreatif (KBKK) terhadap murid, tetapi bagi penyelidikan yang melibatkan kecenderungan pemikiran kritis murid adalah kurang dijalankan oleh kebanyakan penyelidik. Sesetengah penyelidik lebih memberi fokus kepada tahap pemikiran kritis murid berbanding dengan kecenderungan pemikiran kritis murid. Kecenderungan pemikiran kritis dan juga pemikiran kritis murid adalah sama penting dan kedua-duanya adalah seiring dalam pembangunan pemikiran kritis murid (Connie, 2006). Kecenderungan pemikiran kritis adalah sangat berkait rapat dengan pendidikan di mana seseorang yang memiliki kecenderungan ini mempunyai kelebihan tertentu seperti cara berfikir, pencapaian akedemik, kemahiran terhadap proses sains dan cara menghadapi sesuatu masalah berbanding dengan individu yang tidak memiliki kemahiran ini (Bakir, 2015). Kecenderungan pemikiran kritis murid masih kurang lagi diekploitasi oleh kebanyakan penyelidik (Qing, Ni, \& Hong, 2010), maka dengan penyelidikan ini akan dapat memberi impak dalam pembangunan kemahiran berfikir secara kritis murid.

\section{PEMIKIRAN KRITIS}

Pemikiran kritis adalah satu intipati yang penting dan perlu diajar dan diterapkan kepada setiap murid terutamanya pada abad ke-21 ini. Huitt (1998) menjelaskan bahawa pemikiran kritis merupakan salah satu elemen yang paling penting untuk kejayaan seseorang dalam abad ke-21, sementara itu Meyers (1986) menegaskan bahawa pelajar mencapai potensi mereka sepenuhnya, sekiranya mereka belajar untuk berfikir dan dapat berfikir secara kritis. Menurut Aizikovitsh dan Cheng (2015) berfikir secara kritis adalah sifat yang perlu dipelajari; iaitu, murid perlu dididik kearah pemikiran kritis, dan bukannya secara semula jadi dilahirkan dengan keupayaan pemikiran kritis. Ini menunjukkan bahawa kemahiran pemikiran kritis ini boleh dibangunkan dan dipupuk kepada setiap individu. Paul (2002) menegaskan bahawa "dalam dunia yang pesat berubah, mencabar dan saling 
pergantungan, pemikiran kritis kini merupakan satu keperluan untuk terus hidup dari segi ekonomi dan juga sosial."

Para penyelidik telah membangunkan banyak definisi yang berbeza dan terma untuk berfikir secara kritis. Sebagai contoh, Andolina (2001) mendefinisikan pemikiran kritis sebagai proses yang merangkumi penilaian sumber yang ada, mengorganisasikannya secara logik, mengenal pasti hubungannya dengan sumbersumber lain atau sedia ada, mempertimbangkan dengan pelbagai keadaan, dan menentukan kepentingannya.

John Dewey, 'bapa' pemikiran kritis moden mendefinisikan ia sebagai pemikiran yang aktif, persistent (terus menerus), dan teliti atau mendalam mengenai sesuatu kepercayaan atau bentuk pengetahuan yang diterima tanpa begitu saja tetapi akan mempertimbangkannya dari pelbagai sudut seperti mempertimbangkan alasan alasan yang dapat menyokongnya sebelum membuat sebarang kesimpulan dan tindakan lanjutan" (Fisher, 2011). Konsep ini adalah sama dengan takrif Scriven dan Paul (https://www.criticalthinking.org/pages/defining-critical-thinking/766) bahawa ia adalah "proses intelektual yang aktif dan mahir dalam mengkonsepkan, mengadaptasi, menganalisis, mensintesis, dan/atau menilai sesuatu maklumat yang diperolehi hasil daripada pemerhatian, pengalaman, renungan (refleksi), penaakulan, atau komunikasi, sebagai panduan kepada kepercayaan dan juga tindakan."

Chaffee (2014) menakrifkan pemikiran kritis sebagai "pemikiran aktif, bertujuan, dan terancang untuk memahami persekitaran secara mendalam dengan menilai pemikiran sendiri dan juga pemikiran orang lain, bagi menjelaskan dan meningkatkan pemahaman diri sendiri." Ia bersependapat dengan pandangan yang di berikan oleh Halpern (2002) dengan mengariskan pemikiran kritis sebagai "pemikiran yang bertujuan, bersebab dan mempunyai matlamat. Pemikiran kritis adalah pemikiran yang melibatkan aktiviti menyelesaikan masalah, merumuskan kesimpulan, menjangkakan kemungkinan, dan membuat keputusan."

Pada tahun 1987, Facione (1990) telah menganjurkan satu penyelidikan yang dikenali sebagai Kaedah Delphi untuk membangunkan definisi pemikiran kritis dan juga satu set amalan yang dapat dipersetujui umum. Kaedah Delphi memerlukan pembentukan panel pakar untuk perbincangan secara interaktif bagi membentuk keputusan dan juga pendapat. Definisi Panel Delphi pemikiran kritis ini terdiri daripada 46 pakar dalam bidang falsafah, psikologi dan pendidikan dan mereka sebulat suara mendefinisi pemikir kritis yang ideal adalah lazimnya bersifat ingin tahu, berpengetahuan, penuh kepercayaan sebab, berfikiran terbuka, fleksibel, adil dalam penilaian, jujur dalam menghadapi perkara yang berat sebelah atau peribadi, 
berhati-hati dalam membuat pertimbangan, bersedia untuk menimbang semula, jelas mengenai isu-isu, teratur dalam perkara-perkara yang kompleks, rajin dalam mencari maklumat yang relevan, munasabah dalam pemilihan kriteria, fokus dalam siasatan, dan berterusan dalam mencari keputusan yang lebih tepat sebagai subjek dan keadaan membuat penyelidikan.

\section{KECENDERUNGAN PEMIKIRAN KRITIS}

Dewey (1930) mentaksirkan bahawa kecenderungan pemikiran kritis ini sebagai tabiat mental dan juga sikap pemikiran reflektif. Ini bermaksud kecenderungan pemikiran kritis merupakan kelaziman dan juga sikap yang sedia ada dalam diri individu tersebut ataupun sikap pemikiran (Ghadi, Kamariah, \& Njie, 2015). Manakala Ennis (1989) mendefinisikan bahawa kecenderungan itu merupakan tindakan atau niat seseorang untuk melakukan sesuatu. Begitu juga dengan Tishman dan Andrade (1996) mengklafikasikan kecenderungan itu sebagai seseorang yang cenderung untuk berfikir secara kritis kearah tingkah laku yang intelektual.

Halpern (1998) telah menggariskan bahawa kecenderungan untuk berfikir secara kritis termasuklah:

1. Kesediaan untuk melibatkan diri secara berterusan terhadap sesuatu tugas yang kompleks.

2. Lazimnya membuat perancangan dalam aktiviti dan menahan mengikut gerak hati.

3. Fleksibel dan berfikiran terbuka

4. Kesanggupan untuk meninggalkan strategi yang tidak produktif dalam usaha untuk memperbaiki diri.

5. Kesedaran tentang realiti sosial yang perlu diatasi (seperti keperluan untuk mendapatkan persetujuan atau kompromi) dalam setiap tindakan.

Kecenderungan pemikiran kritis adalah sangat penting dan perlu diterapkan di kalangan murid dan bukannya hanya kemahiran pemikiran kritis sahaja yang perlu diambil perhatian dan diberi pembangunan kepada murid sahaja (Connie, 2006) tetapi kecenderungan untuk berfikir secara kritis dan kemahiran untuk berfikir secara kritis perlu dibangunkan bersama-sama dan seiring. Melalui pembangunan kecenderungan pemikiran kritis terhadap murid akan memberi impak kejayaan kepada murid di sekolah dan juga sepanjang hayat mereka (Halpern, 1998). 
Seperti kemahiran pemikiran kritis, kecenderungan pemikiran kritis juga mempunyai pelbagai definisi dan panggilan yang diberikan oleh para ilmuan (Lewis, 2012). Kecenderungan pemikiran kritis adalah merujuk kepada motivasi dalaman seseorang untuk berfikir secara kritis apabila berhadapan dengan sesuatu masalah dalam mencari jalan penyelesaiannya, idea-idea untuk menilai, atau dalam membuat sebarang keputusan (Facione \& Facione, 1997). Kadang-kadang kecenderungan juga dirujuk sebagai etika seorang pemikir kritis (Sears \& Parsons, 1991) atau semangat kritis (Orr \& Klein, 1991), sikap, nilai, dan kecenderungan serta tabiat minda (Aizikovitsh \& Cheng, 2015). Ianya adalah dimensi personaliti seseorang yang berkaitan dengan bagaimana mungkin seseorang itu mengenal pasti masalah dan juga penyelesaian masalah dengan menggunakan pemikiran.

\section{OBJEKTIF KAJIAN}

Objektif utama penyelidikan ini adalah untuk meninjau sejauh mana tahap kemahiran pemikiran kritis murid, tahap kecenderungan pemikiran kritis murid tingkatan dua dalam mata pelajaran Kemahiran Hidup Bersepadu (KHB) di negeri Kedah dan melihat hubungan diantara kedua-dua pemboleh ubah.

\section{PERSOALAN KAJIAN}

1. Apakah tahap kemahiran pemikiran kritis di kalangan murid tingkatan dua dalam mata pelajaran KHB?

2. Apakah tahap kecenderungan pemikiran kritis murid dalam mata pelajaran KHB?

3. Adakah terdapat hubungan signifikan antara kecenderungan pemikiran kritis dengan pemikiran kritis murid dalam mata pelajaran KHB?

\section{METODOLOGI KAJIAN}

Penyelidikan ini merupakan penyelidikan berbentuk deskriptif kuantitatif dan statisitik inferensi. Reka bentuk kajian deskriptif adalah bertujuan untuk memberi penerangan dan penjelasan yang sistematik mengenai fakta dan ciri-ciri sesuatu populasi atau bidang secara fakta dan tepat (Sidek Mohd Noah, 2002). Tahap pemikiran kritis murid diukur dengan menggunakan satu set ujian kemahiran pemikiran kritis Cornell Critical Thinking Test-Level X (CCTT-X) yang diterjermahkan dengan kebenaran ke dalam bahasa Malaysia yang dibangunkan 
oleh Robert H. Ennis, Thomas N. Tomko dan Jason Millman (Ennis, Millman, \& Tomko, 1980). Ujian pemikiran kritis Cornell telah digunakan secara meluas dalam kebanyakan penyelidikan semenjak ianya dibangunkan pada tahun 1985. Ujian pemikiran kritis CCTT-X ini terdiri daripada 71 soalan pelbagai jawapan (3 pilihan) dan murid perlu menjawabnya dalam tempoh masa 50 minit sehingga 60 minit. Ujian ini dapat mengukur kemahiran pemikiran kritis murid yang terdiri daripada empat aspek iaitu induksi, deduksi, kredibiliti peryataan (kebolehpercayaan kenyataan) dan juga mengenal pasti andaian (Shidrah \& Mat, 2012). Manakala bagi menentukan tahap kecenderungan pemikiran kritis murid, kajian menggunakan instrumen yang dibangunkan oleh Universiti Florida iaitu University of Florida - Engagement, Maturity and Innovativeness (UF/EMI) yang dibangunkan oleh John C. Ricketts (Ricketts, 2003). Responden kajian terdiri daripada murid-murid tingkatan dua yang berjumlah 370 orang. Dapatan penyelidikan ini dapat memberi maklumat untuk mencapai objektif yang telah ditetapkan. Data kajian dianalisis menggunakan perisian SPSS dengan menggunakan statistik deskriptif seperti min dan sisihan piawai serata statistik inferensi iaitu korelasi Pearson. Penentuan tahap pemikiran kritis murid diukur berdasarkan pemarkahan dari Kementerian Pendidikan Malaysia (Marlina Ali \& Shaharom Nordin, 2006; Siti Rahayah Ariffin et al., 2008) (Rujuk Jadual 1).

Jadual 1. Jadual pemarkahan Kementerian Pendidikan Malaysia

\begin{tabular}{cc}
\hline Julat markah $(\%)$ & Tahap Penguasaan murid \\
\hline $80-100$ & Cemerlang \\
$60-79$ & Baik \\
$40-59$ & Sederhana \\
$20-39$ & Lemah \\
$0-19$ & Sangat lemah \\
\hline
\end{tabular}

\section{DAPATAN DAN PERBINCANGAN}

Analisis data daripada ujian pemikiran kritis Cornell untuk penentuan tahap kemahiran pemikiran kritis murid tingkatan dua dalam mata pelajaran KHB di negeri Kedah secara keseluruhan adalah seperti dalam Jadual 2.

Jadual 2 menunjukkan nilai min dan sisihan piawai bagi tahap kemahiran pemikiran kritis murid dalam mata pelajaran KHB. Secara keseluruhannya tahap kemahiran pemikiran kritis murid berada pada tahap lemah iaitu min 30.60 dengan sisihan piawai ialah 6.10. Perincian nilai min dan sisihan piawai bagi sub-konstruk pemikiran kritis iaitu Induksi min 11.31 dengan sisihan piawai ialah 
3.27 menunjukkan pada tahap sederhana, Kredibiliti pertanyaan min 9.67 (Sisihan piawai $=2.48)$ berada pada tahap lemah, Deduksi min $6.27($ Sisihan piawai $=2.23)$ juga menunjukkan pada tahap lemah dan begitu juga bagi sub-konstruk mengenal pasti andaian min sebanyak 3.35 (Sisihan piawai $=1.57$ ). Perincian tahap ini adalah berdasarkan kepada manual pentadbiran Ujian Pemikiran Kritis Cornell-Level X (Ennis et al., 1980).

Jadual 2. Skor min dan sisihan piawai pemboleh ubah kajian $(\mathrm{N}=370)$

\begin{tabular}{lcc}
\hline \multicolumn{1}{c}{ Pemboleh ubah } & Min & Sisihan piawai \\
\hline Ujian Pemikiran Kritis Cornell $^{*}$ & 30.60 & 6.10 \\
Induksi & 11.31 & 3.27 \\
Deduksi & 9.67 & 2.48 \\
Kredibiliti & 6.27 & 2.23 \\
Andaian & 3.35 & 1.57 \\
\hline
\end{tabular}

Jadual 3. Tahap ujian pemikiran kritis murid tingkatan $2(\mathrm{~N}=370)$

\begin{tabular}{lclcccc}
\hline $\begin{array}{c}\text { Pemboleh } \\
\text { ubah }\end{array}$ & $\begin{array}{c}\text { Skor } \\
\text { markah }\end{array}$ & \multicolumn{1}{c}{ Tahap } & Bilangan & Peratus & $\begin{array}{c}\text { Skor } \\
\text { minimum }\end{array}$ & $\begin{array}{c}\text { Skor } \\
\text { maksimum }\end{array}$ \\
\hline Ujian & $0-14$ & Sangat lemah & - & - & 17 & 50 \\
Pemikiran & $15-30$ & Lemah & 190 & 51.4 & & \\
Kritis & $31-46$ & Sederhana & 179 & 48.4 & & \\
& $47-62$ & Baik & 1 & 0.3 & & \\
& $63-71$ & Cemerlang & - & - & & \\
\hline
\end{tabular}

Nota: Min minimum $=0 ;$ min maksimum $=71$

Secara terperinci hasil kajian mendapati, tahap kemahiran murid dalam ujian pemikiran kritis menunjukkan sebahagian besar murid mencapai tahap lemah, iaitu seramai 190 orang $(51.4 \%)$ dan tahap sederhana seramai 179 orang (48.4\%). Hanya seorang murid $(0.3 \%)$ mencapai tahap baik. Manakala bagi tahap cemerlang, tiada murid mencapai tahap tersebut. Namun apabila diperhalusi mengikut bilangan dan peratusan, tiada perbezaan yang ketara antara tahap lemah dan sederhana iaitu perbezaan sebanyak 11 orang murid atau $2 \%$ sahaja. Minimum skor yang diperolehi oleh keseluruhan murid ialah sebanyak 17 markah iaitu markah paling rendah yang diperolehi, manakala skor yang tertinggi iaitu maksimun diperolehi sebanyak 50 markah.

Secara keseluruhannya, berdasar kepada tahap yang dikeluarkan oleh Kementerian Pendidikan (Marlina Ali \& Shaharom Nordin, 2006; Siti Rahayah Ariffin et al., 2008) kebanyakan murid berada pada tahap yang lemah dalam kemahiran pemikiran 
kritis bagi mata pelajaran Kemahiran Hidup Bersepadu tingkatan dua Malaysia. Dapatan ini selari dengan dapatan kajian yang dibuat oleh Ismail, Abdul Aziz dan Husin (2007) terhadap 261 pelajar diploma di Universiti Teknologi Mara, di mana telah mendapati kebanyakan pelajar memiliki kemahiran pemikiran kritis yang lemah. Ini menunjukkan kebanyakkan murid lemah dalam kemahiran pemikiran kritis dari segi membuat inferensi secara induksi, kebolehpercayaan terhadap sumber (kredibiliti) dan pemerhatian, deduksi dan mengenal pasti andaian. Namun begitu perbezaannya hanyalah sedikit berbanding dengan murid yang mendapat tahap sederhana dalam pemikiran kritis iaitu cuma 3\% sahaja. Ini menunjukkan bahawa walaupun secara keseluruhannya ia lemah tetapi tidak mencerminkan tahap pemikiran kritis murid adalah lemah kerana perbezaannya hanyalah sedikit sahaja. walaupun dapatan kajian ini selari dengan kajian yang dibuat oleh Ismail et al. (2007) akan tetapi perbezaan umur mereka adalah sangat ketara iaitu murid tingkatan dua dan pelajar universiti namun tahap pemikiran kritis mereka adalah pada tahap yang sama. Ini menggambarkan bahawa pembangunan pemikiran kritis murid masih tidak dapat dicapai.

Analisis data daripada soal selidik (instrumen) kecenderungan pemikiran kritis untuk penentuan tahap kecenderungan pemikiran kritis murid tingkatan dua dalam mata pelajaran KHB di negeri Kedah secara keseluruhan adalah seperti dalam Jadual 4.

Jadual 4. Skor min dan sisihan piawai pemboleh ubah kajian $(\mathrm{N}=370)$

\begin{tabular}{lrc}
\hline \multicolumn{1}{c}{ Pemboleh ubah } & \multicolumn{1}{c}{ Min } & Sisihan piawai \\
\hline Kecenderungan Pemikiran Kritis* & 119.45 & 12.66 \\
Inovatif & 35.04 & 4.26 \\
Kematangan kognitif & 24.05 & 3.35 \\
Penglibatan & 60.35 & 7.55 \\
\hline
\end{tabular}

Berdasarkan kepada hasil analisis dapatan, kecenderungan pemikiran kritis murid boleh dikatakan berada pada tahap kuat iaitu min ialah 119.45 dengan sisihan piawai ialah 12.66. Sementara apabila dilihat secara terperinci bagi setiap subkonstruk kecenderungan pemikiran kritis pula ialah min 35.04 dengan sisihan 4.26 bagi sub-konstruk inovatif, min 24.05 dan sisihan piawai sebanyak 3.35 bagi subkonstruk kematangan kognitif dan sub-konstruk penglibatan min sebanyak 60.35 dan sisihan piawai sebanyak 7.55.

Selain daripada itu, gambaran yang menyeluruh mengenai tahap kecenderungan pemikiran kritis murid perlu dilihat dengan menganalisis dapatan secara terus subkonstruk kecenderungan pemikiran kritis iaitu dari segi keinovasian, kematangan kognitif dan juga penglibatan. 
Jadual 5 menunjukkan tahap dimensi kecenderungan pemikiran kritis murid tingkatan dua secara terperinci mengikut sub-konstruk. Bagi dimensi inovatif (keinovasian), majoriti murid berada pada tahap kecenderungan pemikiran kritis yang kuat iaitu seramai 317 (85.7\%) orang murid berbanding dengan tahap kecenderungan pemikiran kritis yang lemah hanya $53(14.3 \%)$ orang murid yang menguasainya. Walau bagaimanapun tiada murid yang berada pada tahap kecenderungan pemikiran kritis yang lemah.

Jadual 5. Tahap dimensi kecenderungan pemikiran kritis murid tingkatan 2

\begin{tabular}{|c|c|c|c|c|}
\hline Pembolehubah & Skor markah & Tahap & Bilangan & Peratus \\
\hline \multirow[t]{3}{*}{ Inovatif } & $0-15$ & $\begin{array}{l}\text { Kecenderungan pemikiran } \\
\text { kritis lemah }\end{array}$ & - & - \\
\hline & $16-30$ & $\begin{array}{l}\text { Kecenderungan pemikiran } \\
\text { kritis sederhana }\end{array}$ & 53 & 14.3 \\
\hline & $31-45$ & $\begin{array}{l}\text { Kecenderungan pemikiran } \\
\text { kritis kuat }\end{array}$ & 317 & 85.7 \\
\hline \multirow[t]{3}{*}{$\begin{array}{l}\text { Kematangan } \\
\text { kognitif }\end{array}$} & $0-11.66$ & $\begin{array}{l}\text { Kecenderungan pemikiran } \\
\text { kritis lemah }\end{array}$ & 1 & 0.3 \\
\hline & $11.67-23.32$ & $\begin{array}{l}\text { Kecenderungan pemikiran } \\
\text { kritis sederhana }\end{array}$ & 150 & 40.5 \\
\hline & $23.33-35.00$ & $\begin{array}{l}\text { Kecenderungan pemikiran } \\
\text { kritis kuat }\end{array}$ & 219 & 59.2 \\
\hline \multirow[t]{3}{*}{ Penglibatan } & $0-26.66$ & $\begin{array}{l}\text { Kecenderungan pemikiran } \\
\text { kritis lemah }\end{array}$ & - & - \\
\hline & $26.67-53.32$ & $\begin{array}{l}\text { Kecenderungan pemikiran } \\
\text { kritis sederhana }\end{array}$ & 64 & 17.3 \\
\hline & $53.33-80.00$ & $\begin{array}{l}\text { Kecenderungan pemikiran } \\
\text { kritis kuat }\end{array}$ & 306 & 82.7 \\
\hline
\end{tabular}

Berdasarkan kepada jadual, juga menunjukkan dimensi yang kedua iaitu kematangan kognitif. Di mana majoriti murid juga berada pada tahap kecenderungan pemikiran kritis yang kuat iaitu seramai 219 (59.2\%) orang murid, manakala tahap kecenderungan pemikiran kritis yang sederhana hanya seramai $150(40.5 \%)$ orang murid. Namun terdapat seorang murid yang memiliki tahap kecenderungan pemikiran kritis yang lemah.

Bagi dimensi atau sub-konstruk yang terakhir sekali iaitu penglibatan, secara keseluruhannya sebilangan besar murid berada pada tahap kecenderungan pemikiran kritis yang kuat. Berbanding dengan tahap kecenderungan yang sederhana iaitu seramai 64 orang murid atau $17.3 \%$, manakala bagi tahap kecenderungan pemikiran kritis yang lemas tiada murid yang memiliki pada 
tahap tersebut. Secara keseluruhannya bagi ketiga-tiga aspek tersebut kebanyakan murid memiliki tahap kecenderungan pemikiran kritis yang kuat. Dapatan juga menunjukkan bahawa murid-murid sangat cenderung untuk berfikir secara kritis kearah tingkah laku yang intelektual. Akan tetapi ianya bertentangan dengan dapatan tahap kemahiran pemikiran kritis murid iaitu pada tahap lemah. Sepatutnya apabila murid mempunyai kecenderungan pemikiran kritis yang kuat, juga mempunyai tahap kemahiran untuk berfikir secara kritis yang tinggi (Ricketts \& Rudd, 2004) dan kecenderungan pemikiran kritis dan juga kemahiran pemikiran kritis adalah bergantungan diantara satu sama lain (Facione, Sanchez, Facione, \& Gainen, 1995).

Berdasarkan kepada analisis dapatan kajian, didapati kebanyakkan murid mempunyai tahap kecenderungan pemikiran kritis yang kuat. Ini menunjukkan murid memiliki kecenderungan untuk berfikir secara kritis yang tinggi dalam mata pelajaran Kemahiran Hidup Bersepadu. Secara keseluruhannya murid memiliki kecenderungan pemikiran kritis yang kuat bagi kesemua dimensi tersebut iaitu dalam aspek inovatif, kematangan kognitif dan juga penglibatan. Dapatan ini menyamai dapatan kajian yang dibuat oleh Friedel, Irani, Rhoades, Fuhrman dan Gallo(2008) yang mendapati kesemua sub-konstruk kecenderungan pemikiran kritis iaitu inovatif, kematangan kognitif dan penglibatan mempunyai kecenderungan pemikiran kritis yang kuat dalam kajian mereka. Manakala bagi dapatan Kamisah, Iksan dan Halim (2007) mendapati murid tingkatan empat aliran sastera dan sains mempunyai kecenderungan untuk berfikir secara kritis yang positif. Namun begitu, dapatan yang diperolehi dalam kajian Ramasamy (2011) sedikit berbeza iaitu menunjukkan mahasiswa Malaysia mempunyai kecenderungan pemikiran kritis yang sederhana positif.

Untuk penentuan kekuatan hubungan, kajian merujuk kepada Cohen (1988) yang mencadangkan garis panduan seperti dalam Jadual 6.

Jadual 6. Tafsiran pekali korelasi

\begin{tabular}{cl}
\hline \multicolumn{1}{c}{ Saiz } & Penerangan \\
\hline$r=.10$ hingga .29 atau $r=-.10$ hingga -.29 & Lemah \\
$r=.30$ hingga .49 atau $r=-.30$ hingga -.49 & Sederhana \\
$r=.50$ hingga 1.0 atau $r=-.50$ hingga -1.0 & Kuat \\
\hline
\end{tabular}

Sumber: Cohen, 1988

Berdasarkan kepada analisis dapatan, kajian mendapati nilai pekali korelasi $r$ bagi hubungan kemahiran pemikiran kritis dengan kecenderungan pemikiran kritis secara keseluruhannya adalah bersamaan dengan $0.16(p=0.01)$. Terdapat 
wujudnya hubungan positif antara tahap kemahiran pemikiran kritis murid dengan kecenderungan pemikiran kritis, dapatan menunjukkan terdapat hubungan yang terus, dimana murid mendapat skor yang tinggi dalam kemahiran pemikiran kritis dan juga memperolehi skor yang tinggi dalam kecenderungan pemikiran kritis. Disebabkan nilai $p=0.01$ adalah lebih kecil dari 0.05 , ini bermakna terdapat hubungan yang signifikan antara pemikiran kritis dengan kecenderungan pemikiran kritis. Namun begitu, merujuk kepada tafsiran pekali korelasi, kekuatan hubungan yang dikenal pasti adalah lemah. Dapatan ini memberi maksud walaupun mempunyai hubungan yang positif tetapi hubungan tersebut adalah sangat lemah.

Namun begitu, apabila analisis dilakukan secara terperinci iaitu melihat hubungan bagi pemboleh ubah bersandar dengan sub-konstruk pemboleh ubah tidak bersandar didapati hanya sub-konstruk inovatif $(r=0.17, n=370, p=.001)$ dan penglibatan ( $r=0.16, n=370, p=.002)$ sahaja mempunyai hubungan yang signifikan tetapi hubungan yang lemah.

Jadual 7. Hubungan antara kecenderungan pemikiran kritis dengan tahap pemikiran kritis murid

\begin{tabular}{lc}
\hline Kecenderungan pemikiran kritis & Tahap pemikiran kritis murid $(r)$ \\
\hline Keseluruhan & $0.16^{*}$ \\
Inovatif & $0.17^{* *}$ \\
Kematangan kognitif & 0.014 \\
Penglibatan & $0.16^{* *}$ \\
\hline
\end{tabular}

Nota: * signifikan pada $p<0.05$

\section{KESIMPULAN}

Kemahiran pemikiran kritis murid dalam kajian ini adalah pada tahap lemah, ia akan memberi impak kepada murid untuk menempuhi masa hadapan yang lebih mencabar di mana ia memerlukan murid untuk berfikir lebih kritis dan kreatif dan bagi melahirkan warganegara yang mempunyai pemikiran aras tinggi tidak akan tercapai. Kegagalan murid untuk berfikir secara kritis dengan baik mungkin dapat dikaitkan dengan proses pengajaran dan pembelajaran yang berlaku di dalam kelas KHB khususnya dan di sekolah amnya, persoalannya sejauh manakah pendidikan di peringkat mata pelajaran KHB dan di sekolah melatih murid-murid ke arah berfikiran kritis, mungkin boleh disimpulkan di sini ia berada pada tahap yang rendah. Oleh itu penyelidik berharap agar pihak Kementerian Pendidikan Malaysia (KPM) umumnya dan guru khasnya agar memberi perhatian yang serius terhadap kelemahan murid-murid untuk berfikir secara kritis dan mengambil langkah-langkah 
bijak bagi menangani perkara ini dengan baik seperti menambahbaik kurikulum dan juga menekankan penilaian yang berasaskan pemikiran aras tinggi. Sekiranya perkara ini berlarutan, maka hasrat untuk melahirkan murid yang mempunyai daya fikir aras tinggi seperti yang dihasratkan dalam Pelan Pembangunan Pendidikan Malaysia 2013-2025 (Kementerian Pendidikan Malaysia, 2013) tidak akan dapat dicapai sepenuhnya.

\section{REFERENCES}

Aizikovitsh, E., \& Cheng, D. (2015). Developing critical thinking skills from dispositions to abilities mathematics education from early childhood to high school. Creative Education, 6, 455-462.

Andolina, M. (2001). Critical thinking for working students. New York: Delmar/Thomson Learning.

Bakir, V. (2015). "Veillant Panoptic Assemblage": Mutual watching and resistance to mass surveillance after Snowden. Media and Communication, 3(3), 12-25. https://doi. org/10.17645/mac.v3i3.277

Chaffee, J. (2014). Thinking critically (11th ed.). U.S.: Cengage Learning.

Cohen J. (1988). Statistical power analysis for the behavioral sciences. New York, NY: Routledge Academic.

Connie, S. L. (2006). Approaches to evaluate critical thinking dispositions. Paper presented at APERA Conference, Hong Kong, 28 - 30 November, pp. 1-8.

Dewey, J. (1930). Individualism: Old and new. New York: Capricorn Books.

Ennis, R. H. (1989). Critical thinking and subject specificity: Clarification and needed research. Educational researcher, 18(3), 4-10. https://doi.org/10.3102/ 0013189X018003004

Ennis, R. H., Millman, J., \& Tomko, T. N. (1980). Cornell critical thinking test administration manual level $X$ and $Z$ (5th ed.). North Bend, OR: The Critical Thinking Co.

Facione, P. A. (1990). The California critical thinking skills test-College level. Technical Report no. 1. Experimental Validation and Content Validity.

Facione N. C., \& Facione, P, A. (1997). Critical Thinking assessment in nursing education programs: An aggregate data analysis. Millbrae, CA: California Academic Press.

Facione, P. A., Sanchez, C. A., Facione, N. C., \& Gainen, J. (1995). The disposition toward critical thinking. Journal of General Education, 44(1), 1-25.

Fisher, A. (2011). Critical thinking: An introduction. Cambridge: Cambridge University Press.

Friedel, C., Irani, T., Rhoades, E., Fuhrman, N., \& Gallo, M. (2008). It's in the genes: Exploring relationships between critical thinking and problem solving in undergraduate agriscience students' solutions to problems in Mendelian genetics. Journal of Agricultural Education, 49(4), 25-37. https://doi.org/10.5032/ jae.2008.04025 
Ghadi I. N., Kamariah A. B., \& Njie B. (2015). Influences of critical thinking dispositions on critical thinking skills of undergraduate students at a Malaysian Public University. Journal of Educational Research and Reviews, 3(2), 23-31.

Halpern, D. F. (1998). Teaching critical thinking for transfer across domains: Disposition, skills, structure training, and metacognitive monitoring. American Psychologist, 53, 449-553. https://doi.org/10.1037/0003-066X.53.4.449

Halpern, D. F. (2002). Thought and knowledge: An introduction to critical thinking. New York: Routledge.

Huitt, W. (1998). Critical thinking: An overview. Educational Psychology Interactive. Valdosta, GA: Valdosta State University.

Ismail, M. R., Abdul Aziz, R., \& Husin, Z. (2007). The use of critical thinking skills among university ESL students. Paper presented at the Second Biennial International Conference on Teaching and Learning of English in Asia : Exploring New Frontiers (TELiA2), 14-16 June 2007, Holiday Villa Beach \& Spa Resort, Langkawi. Faculty of Communication and Modern Languages, Universiti Utara Malaysia, Sintok, 1-14.

Kamisah, O., Iksan, Z. H., \& Halim, L. (2007). Sikap terhadap sains dan sikap saintifik di kalangan pelajar sains. Jurnal Pendidikan, 32, 39-60.

Kementerian Pendidikan Malaysia. (2002). Huraian Sukatan Pelajaran Kemahiran Hidup Sekolah Rendah Tahun 5. Putrajaya: Pusat Perkembangan Kurikulum.

Kementerian Pendidikan Tinggi Malaysia. (2013). Laporan awal pelan pembangunan pendidikan Malaysia 2013-2025. Putrajaya: Kementerian Pendidikan Tinggi.

Lewis, V. (2012). The power of critical thinking. Oxford: Oxford university Press.

Meyers, C. (1986). Teaching students to think critically. San Francisco, CA: Jossey-Bass Inc. Publishers.

Marlina Ali \& Shaharom Nordin. (2006). Tahap penguasaan kemahiran berfikir kritis di kalangan pelajar pendidikan fizik merentas jantina. Buletin Persatuan Pendidikan Sains dan Matematik Johor, 15(1), 99-110.

Mohd. Najib Razak. (2012). Asli's 16th Malaysian education summit - Transformation in Motion: Opportunities and Challenges for Malaysian Education.

Orr, J. B., \& Klein, M. F. (1991). Instruction in critical thinking as a form of character education. Journal of Curriculum and Supervision, 6(2), 130-144.

Paul, R. W. (2002). The international center for the assessment of thinking: Critical thinking essay examination. Santa Rosa, CA: Foundation for Critical Thinking.

Perkins, D., Jay, E., \& Tishman, S. (1993). Beyond abilities: A dispositional theory of thinking. Merrill-Palmer Quarterly, 39, 1-21.

Qing, Z., Ni, S, \& Hong, T. (2010). Developing critical thinking disposition by task-based learning in chemistry experiment teaching. Procedia-Social and Behavioral Sciences, 2(2), 4561-4570. https://doi.org/10.1016/j.sbspro.2010.03.731

Ramasamy, S. (2011). An analysis of informal reasoning fallacy and critical thinking dispositions among Malaysian undergraduates. Retrieved from https://files.eric. ed.gov/fulltext/ED525513.pdf

Ricketts, J. C. (2003). The efficacy of leadership developement, critical thinking dispositions, and student acedemic performance on the critical thinking skills of selected youth leaders. Unpublished doctoral dissertation, University of Florida. 
Ricketts, J. C., \& Rudd, R. D. (2004). The relationship between critical thinking dispositions and critical thinking skills of selected youth leaders in the national FFA organization. Journal of Southern Agricultural Education Research, 54(1), 21-33.

Sears, A., \& Parsons, J. (1991). Towards critical thinking as an ethic. Theory and Research in Social Education, 19(1), 4-68.

Shidrah, N., \& Mat, B. (2012). Developing critical thinking skills in tertiary academic writings through the use of an instructional rubric for peer evaluation. Unpublished doctoral dissertation, University of Canterbury.

Sidek Mohd. Noah (2002). Reka bentuk penyelidikan falsafah, teori dan praktis. Serdang, Selangor: Universiti Putra Malaysia.

Siti Rahayah Ariffin, Zolkefli Haron, Rodiah Idris, Nur 'Ashiqn Najmuddin, Shahrir Samsuri, Basri Hassan, \& Nor Azaheen Abdul Hamid (2008). Tahap penguasaan kemahiran pemikiran kritikal dan penyelesaian masalah pelajar sains dan hubungannya dengan pencapaian. Paper presented at Prosiding Seminar Pendidikan Kejuruteraan Dan Alam Bina (PEKA 2008), Fakulti Kejuruteraan dan Alambina, Universiti Kebangsaan Malaysia, 15-23.

Tishman, S., \& Andrade, A. (1996). Thinking dispositions: A review of current theories, practices, and issues. Cambridge, MA: Project Zero, Harvard University. 